\title{
Foreign Portfolio Investment Response to Monetary Policy Decisions in Nigeria: A Toda-Yamamoto Approach
}

\author{
Gylych Jelilov $^{1}$, Bilal Celik ${ }^{1} \&$ Yusuf Adamu ${ }^{2}$ \\ ${ }^{1}$ Nile University of Nigeria, Nigeria \\ ${ }^{2}$ Central Bank of Nigeria, Nigeria \\ Correspondence: Gylych Jelilov, Nile University of Nigeria, Nigeria.
}

Received: January 21, 2020

Accepted: February 24, 2020

Online Published: February 27, 2020

doi:10.5539/ibr.v13n3p166

URL: https://doi.org/10.5539/ibr.v13n3p166

\begin{abstract}
This paper examined the response of foreign portfolio investment to Monetary Policy decisions of the Central Bank of Nigeria using monthly data spanning January 2007 to December 2018. The study adopted the Toda-Yamamoto Causality model and Generalized Impulse Response Function for analysis. The results showed that changes in monetary policy stance could only impact the behavior of foreign portfolio investment with 6-month lag and with marginal impact. This implies that monetary policy could still be effective even if the CBN decides to lose policy stance without losing significant capital flight. The conclusion from the findings is that monetary policy is just a signaling instrument for portfolio investors in Nigeria because it influences foreign portfolio investment through the Treasury bill rate rather than through MPR and CRR. The marginal response of investment due to changes in policy rate from the GIRF validate the TY results by indicating that monetary policy rate changes on its own may not be what investors are concern about, rather the expectation of the rates future path. The cash reserve ratio as a monetary policy tool does not seem to exert any impact on foreign portfolio investment.
\end{abstract}

Keywords: foreign portfolio investment, monetary policy, Toda-Yamamoto

JEL Classification: G11, E52, C59

\section{Introduction}

Portfolio Investment plays a key role in the economic life of any country. Many countries rely on portfolio inflows to argument their demand for foreign exchange. However, these portfolio inflows as important as they are, depend on many factors, key among all, is the rate of interest operative in the attracting economy. The level of interest rates in every economy is determined by the monetary authority of that country through its monetary policy decisions. Interest rate is critical in the monetary policy transmission and monetary policy resolutions can be propagated to the real sector via this channel to impact the level of investments including foreign portfolio investments.

Monetary policy decisions through the manipulation of interest rate have a different implication for the general investment climate in an economy. For instance, a high-interest rate in the economy is attractive to foreign portfolio investors. So and if the aim of the monetary authority is to attract more foreign exchange, then high interest would be considered as policy stance. However, a high-interest rate may also imply a high cost of borrowing which will discourage domestic investment because the cost of production will raise thereby dampens private investment. From the foregoing, it means that certain tradeoffs had to happen in either direction that the monetary authority chose to influence interest rate. Understanding the link between the interest rate and investment is, therefore, of great imperative to policymakers.

In Nigeria, the CBN has recently been battling with its own decision on the monetary policy rate (MPR) and other monetary policy tools such as the Cash Reserve Ratio (CRR) based on prevailing monetary conditions. This is in an attempt to anchor other rates in the market and enhance competition among the deposit money banks (DMBs) towards enthroning a free market system for loanable funds in Nigeria (Golit, Adamu and Belonwu 2018). It was in line with this statutory mandate that the Bank chose to maintain the MPR at 14 percent during the recent economic recession, despite the public uproar in favor of a lower interest rate regime to propel the economy out of recession. The Bank's decision to retain the MPR at a high rate was based on its 
conviction that the higher rates would argument the foreign exchange (FX) demand that was stiff at that time. The question, however, is by what magnitude will the high rate attract portfolio investment and by extension the FX? Is the MPR and the CRR the only variables investors considered, or are there other variables, if yes what are those variables? The other question is if the Bank decides to reduce the rate against the fear of capital flight, by how much would it lose FX? Is the quantum of loss significant enough to affect the workings of the economy compared to what higher interest rate would provide? And so many other questions.

It is in an attempt to examine some of these questions that this study is undertaken to investigate if key monetary policy instruments of the CBN influences the decision of portfolio investors in Nigeria. The significance of the study is stressed by the need to offer a clearer understanding of the features of foreign portfolio investment and its interaction with the key monetary policy instrument in Nigeria.

The article is structured into five sections with the introduction in section one. Section two reviews theoretical and empirical literature, present stylized facts on the interest rate and foreign portfolio investment in Nigeria. The methodology, encapsulating the data and model specification, estimation and analysis of results are in Section three, while the policy implications are in section four. Section five provides the concluding remarks.

\section{Literature Review}

\subsection{Theoretical Literature}

Several theories explaining the relationship between the interest rate and portfolio choice exist. However, it would be cumbersome to review all in a single study. In view of this, an effort was made to focus only on the relevant modern theoretical underpinning that relates to this study. One of the relevant frameworks explaining portfolio investment is the Markowitz' model of 1991 popularly referred to as the Modern Portfolio Theory (MPT). The model provided a lucid explanation of the impact on portfolio diversification by the number of assets contained in a portfolio and covariance relationships. It optimizes portfolio expected return for a specified quantity of portfolio risk. The central idea behind the MPT is that securities in an investment portfolio should not be chosen independently, on their own qualities.

The theory stimulates asset diversification to hedge against market risk and risk peculiar to a particular firm. Investment decision method aid firms to categorize, approximate, and regulate expected risk and return. Tangential to the theory is its quantification of the nexus between risk and return and the conjecture that investors must be compensated for assuming the risk. Nonetheless, diversification reduces risk even if assets' returns are not negatively correlated-indeed, even if they are positively correlated (Omiosre, et al (2012).

The Portfolio Balance Theories, on the other hand, assert that by decreasing maturity and the duration of risk in the market, purchases of long-term assets decrease the return that investors demand that specific duration risk. This is due to the fact that purchaser of specific duration risk is willing to pay a higher price for it (Golit, Adamu, and Belonwu 2018).

The habitat models is another framework that explained the conduct of investors in the market. The models focus on varied investor preferences and insufficient substitutability between maturities and security types (Vayanos \& Vila, 2005). These models elucidate the role of two classes of investors, based on choices for specific maturities and risk-averse arbitrageurs. Arbitrageurs move in line with the yield curve based on the route of shocks in a specified maturity that reduces yield. Confronted with a demand shock in a given maturity that reduces returns, arbitrageurs will move along the yield curve searching for other higher yielding investment opportunities, while other investors, with a preference for that particular maturity, remain. The response of arbitrageurs based on particular shocks explicates the channel through which shocks are propagated to a given maturity along the yield curve.

To link the above ideas to this study, the workings of the framework in investment decision making is better understood when the monetary policy expectations are associated with market interest rate variables. Going by the expectation theory of the term structure of interest rates, the factors affecting assets could be explained through the anticipated future path of interest rates (Kim and Wright, 2005). This concerns the market outlook of how the monetary authority, in this case, the CBN would fix the MPR over time. If agents in the market anticipate a hike in the policy rate in the future, returns on securities with adequately long remaining maturities would increase. To this end, a change in market expectations for monetary policy would have a contemporaneous impact on securities, reflecting a revised path of anticipated future interest rates. At the same time, returns can fluctuate due to a multitude of factors distinct to changes in the anticipated path of future short-term interest rates, captured by the term premium (Robin Koepke 2018). 


\subsection{Empirical Literature}

The literature on foreign portfolio investments flows to developing economies has assertively recognized the prominence of both economy-specific attributes and global attributes. The country-specific attributes relate to progress, economy's risk and return prospects in the market. On the other hand, global attributes affect the availability of foreign capital and relate to global financial conditions, such as interest rate, market, environment, and risk. Literature has also considered a range of monetary policy tools that could propel investment. With respect to portfolio investment, monetary policy had been confirmed statistically to exert effect positively. For instance, Conover et al. (2008) opined that monetary policy is a useful pointer in influencing when to choose between aggressive or defensive stock portfolios. The paper also found that Fed easing favors cyclical stocks while Fed tightening favors defensive stocks.

Ammera, et al (2018) examined the impact of interest rates on portfolio investments and found that lower interest rates resulted in huge flows to the US. Robin Koepke (2018) examined the Fed policy anticipations and portfolio flows to developing markets and found that it is mainly the element of monetary policy that affects emerging markets portfolio inflows. A change in market expectations towards easier future U.S. monetary policy resulted in larger emerging market portfolio inflows, while an upward change in interest rate anticipations reduces such flows. Johnson, \& Mercer (2005) examined the nexus between U.S. monetary policy and global assets returns and found that U.S. monetary policy has a strong association with security returns. U.S. stock returns were found to be steadily higher and less volatile when the Federal Reserve follows a loose monetary policy. Still on the U.S economy, Fratzscher, Saborowski, and Straub (2009) investigated the impact of monetary policy on portfolio investment and found that monetary policy exerts a considerable effect on capital flows and trade balance.

Flageollet et al (2016) examined the impact of monetary policy on stock and bond returns co-movement and their repercussions to risk-based asset allocation. The study identified three co-movement regimes and established that risk-based portfolio strategies did not perform well in the low correlation regime which features inflation shocks. Fanelli (2017) studied the nexus among monetary policy, capital controls, and international portfolios and found that as insurance considerations gained more prominence, domestic-currency positions become greater, and the excess-return volatility of domestic-currency securities actually decrease, rather than increase. Carvalho and Fidora (2015), also found that the increase in foreign holdings of euro area bonds is related to a decrease of euro area long-term interest rates.

In Nigeria, Ayodele, et al (2017) examined the impact of interest rate on portfolio investments and found that the prime lending rate significantly influenced portfolio investment. Golit, Adamu, and Belonwu (2018) examine whether or not the Monetary Policy Rate (MPR) of the Central Bank of Nigeria (CBN) is a signalling instrument for foreign portfolio investors and found that changes in the monetary policy rate of the CBN impact the behaviour of foreign portfolio investment in Nigeria. Also, Bilal, Akanimo and Ademola (2019) investigated the Effects of an Unchanged Monetary Policy Rate in Nigeria's Economic Growth and found that an unchanged MPR had a negative impact on the foreign direct investment.

Siddiqui and Aumeboonsuke (2014) examined the nexus between FDI and interest rates within 5 Asian countries and found that interest rates have a negative relationship with foreign direct investments into those countries. Waqasa, Hashmia, and Nazir (2015) investigated the relationship between macroeconomic factors and foreign portfolio investment volatility in South Asian countries and found the existing of a significant relationship between macroeconomic factors and foreign portfolio investment volatility.

\subsection{Stylized Facts}

Nigeria like other developing countries have been experiencing ups and downs in its capital flows with the recent ones in the upward trajectory. This development has been attributed to a low level of financial development in the country. Investors are said to take advantage of the less integrated nature of developing countries' financial markets because such markets are believed to offer higher returns and temporal safe haven opportunities for capital inflows. From 2007 equity portfolio dominated total foreign portfolio investments into the country followed by capital inflows directed at money market instruments. Portfolio investments related to bonds were the least dominant (Fig 1). 


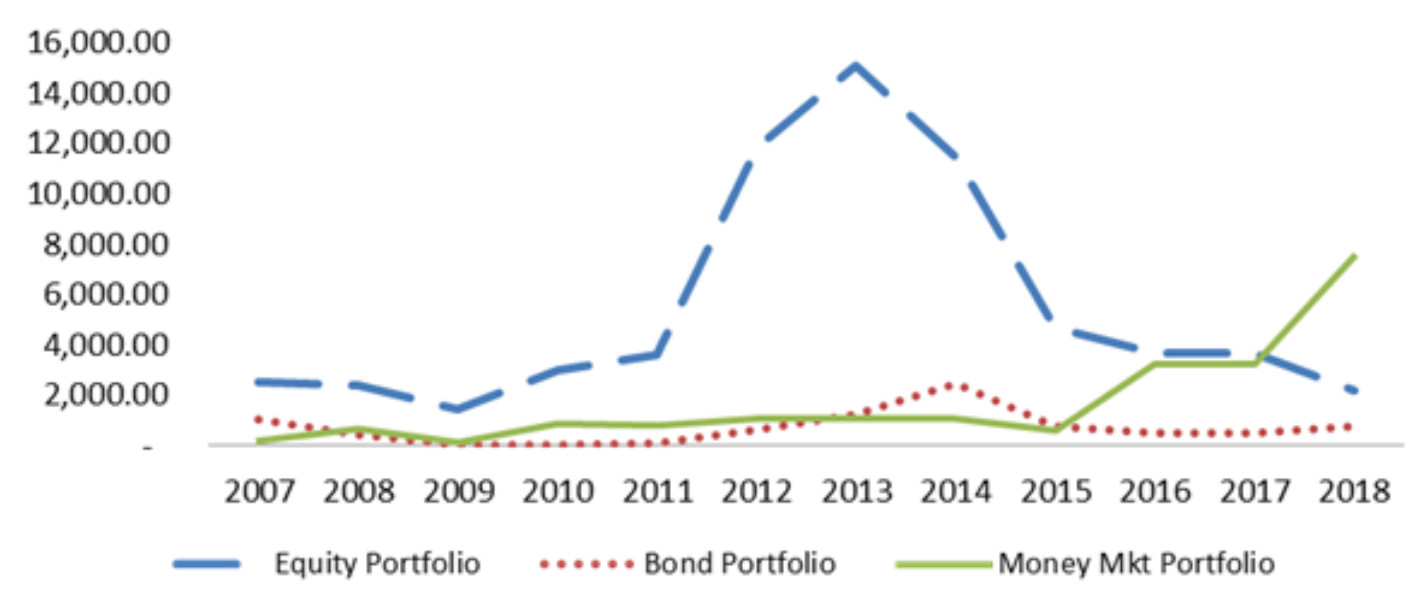

Figure 1. Total Foreign Portfolio Inflows into Nigeria (US\$ billion)

Source: Central Bank of Nigeria

The equity portfolio continued on the rising trend until 2008 where it started to decrease as a result of the 2008 global financial crisis. The equity inflows declined to US $\$ 1.4$ bn in 2009 from US $\$ 2.5 b n$ in 2007 but had a rapid recovery up till 2013 when it nosedives again. This ups and downs were observed to persist, responding to different economic circumstances operating. Capital inflows increased persistently afterward peaking at US $\$ 15.1 \mathrm{bn}$ in 2013 before declining consistently afterward in response to monetary policy normalization of the US Federal Reserve, and the domestic risks accompanying the Nigerian elections in 2015, as well as, the macroeconomic contraction that preceded the 2016 economic recession in the country. However, capital inflow into money market instruments remained stable for most of the time but recorded a consistent increase from 2015.

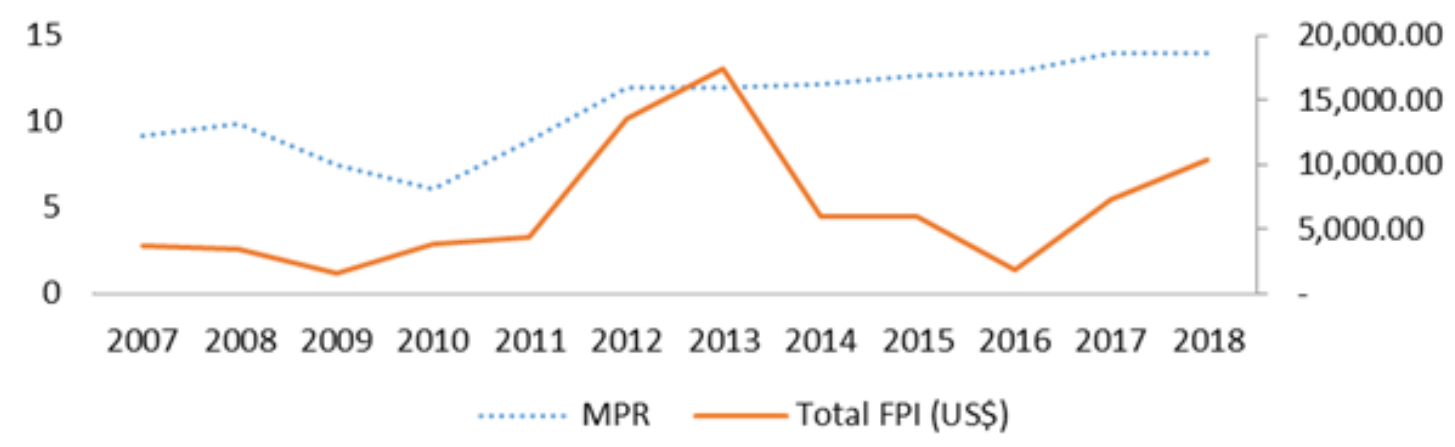

Figure 2. Monetary Policy Rate and Total Foreign Portfolio Investments

Source: Central Bank of Nigeria

From figure 2, the MPR appears to be driving foreign portfolio inflows from 2007 up till 2014. The pattern, however, became irregular afterward as the direction of inflow showed that despite the MPR, inflow declined between 2014 and 2016. This graphical trend may imply that the MPR may not be the main instrument investors take into account when deciding to invest or not.

\subsection{MPR and Other Short-Term Interest Rates}

The graphical presentation of the policy rate with other interest rates revealed that all the rates trend the same direction on average. However, the volatility in trends differs amongst rates. The interbank call rate appears to be the most volatile of all the rates, followed by prime lending rates, treasury bill rates, maximum lending rates, and the monetary rate in that order. 
PLR

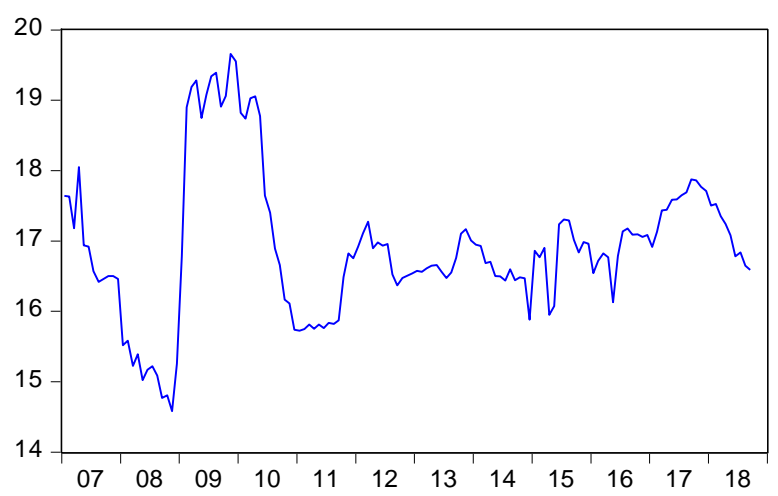

MLR

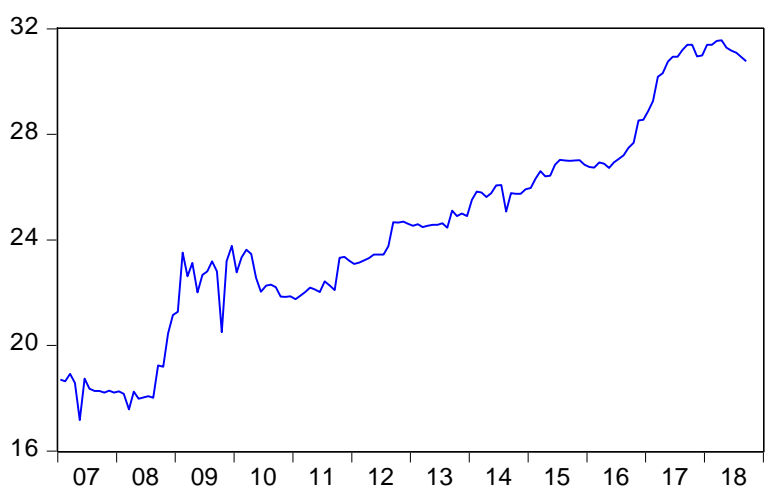

TBR

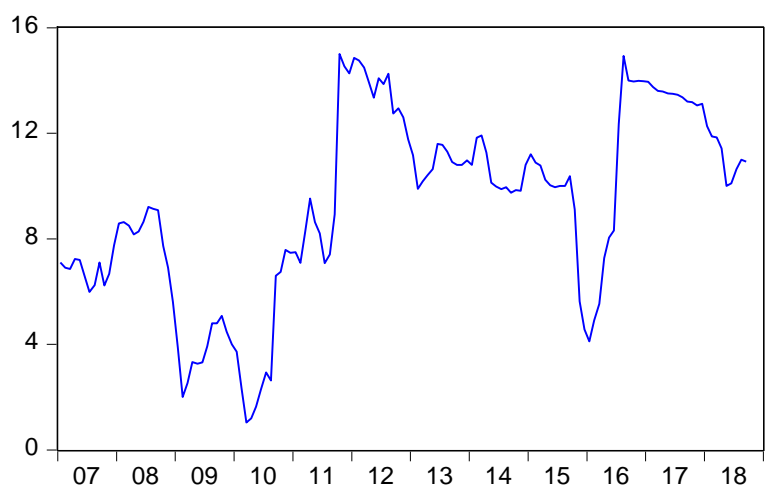

MPR

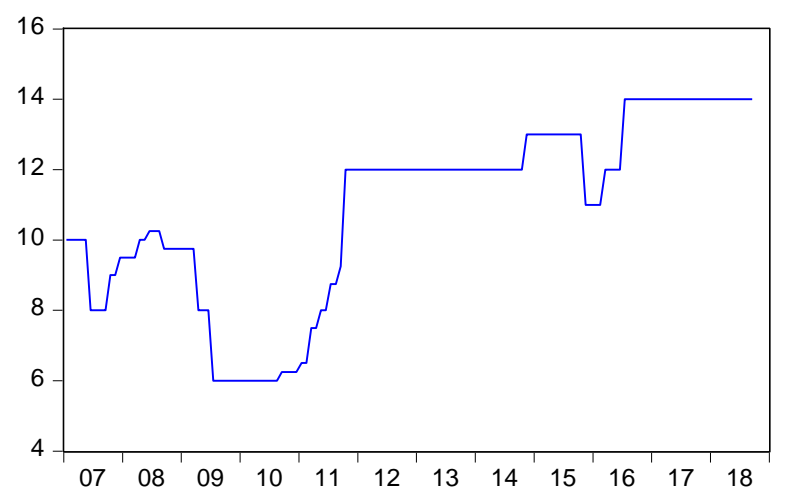

IBCR

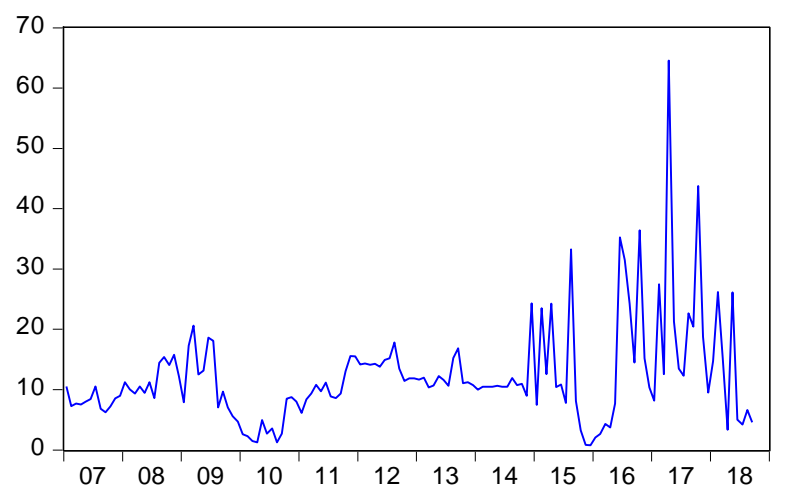

Figure 3. graphical presentation of interest rates

\section{Methodology}

\subsection{Data}

The study used monthly data spanning January 2007 to December 2018. The variables include the foreign portfolio investment (FPI), monetary policy rate (MPR), Cash reserve ratio (CRR) external reserve (RESV), Consumer Price Index (CPI), Treasury bill rate and interbank exchange rate (IBEXR). The data were sourced from the CBN Statistical Bulletin. Foreign portfolio investment, Cash Reserve Ratio and Monetary Policy Rate are the main variables adopted in examining how portfolio investors respond to the monetary policy. The Nigerian external reserve (RESV) was used to gauge the risk appetite of investors since most of them watch out for reserve levels to guarantee capital reversal. 


\subsubsection{Descriptive Statistics}

Table 1 was based on 144 observations (after adjustment), hence providing a more precise estimate of the parameters. The variables presented a positive mean for all series with MPR having a mean of 10.92 percent and a standard deviation of 2.64 percent. The CRR showed a mean of 11.76 percent with a standard deviation of 9.1 percent. The TBR showed a mean of 9.3 percent with a standard deviation of 3.5 percent. EXR showed a mean value of 186.64 and a standard deviation of 64.90, RESV has a mean of $\$ 7.09$ billion and a standard deviation of 2.3 , while the TFPI showed a mean of $\$ 3.09$ billion and a standard deviation of 2.3 The Jarque-Bera statistics indicated that the null hypothesis of the variables should be rejected at 5 percent level of significant indicating that all the variables are normally distributed. All the variables, but MPR and TBR had positive skewness value with TFPI having the highest positive of 8.0 while CRR had the lowest positive of 0.2. In terms of the Kurtosis statistics, all the variables showed positive values with the highest and lowest value of 66.3 and 1.6 for TFPI and CRR, respectively.

Table 1. Regression Analysis

\begin{tabular}{|l|l|l|l|l|l|l|l|}
\hline & TFPI & MPR & CRR & TBR & EIBR & HCPI & RESV \\
\hline Mean & $3.09 \mathrm{E}+09$ & 10.92188 & 11.76389 & 9.271493 & 186.6416 & 149.7008 & 7091152 \\
\hline Median & 62090712 & 12 & 12 & 9.95 & 158.9 & 141.502 & 6260810 \\
\hline Maximum & $1.95 \mathrm{E}+11$ & 14 & 31 & 15 & 309.73 & 274.57 & 14497594 \\
\hline Minimum & 2486243 & 6 & 1 & 1.04 & 116.79 & 72.8187 & 4935940 \\
\hline Std. Dev. & $2.27 \mathrm{E}+10$ & 2.636728 & 9.147384 & 3.536671 & 64.89784 & 56.67981 & 2363165 \\
\hline Skewness & 8.012181 & -0.608353 & 0.258248 & -0.404263 & 1.064681 & 0.586126 & 1.890336 \\
\hline Kurtosis & 66.34618 & 2.171275 & 1.639925 & 2.348982 & 2.601563 & 2.318949 & 5.710367 \\
\hline & & & & & & & \\
\hline Jarque-Bera & 25617.12 & 13.00296 & 12.69944 & 6.465237 & 28.15759 & 11.02803 & 129.8374 \\
\hline Probability & 0 & 0.001501 & 0.001747 & 0.039454 & 0.000001 & 0.00403 & 0 \\
\hline & & & & & & & \\
\hline Sum & $4.45 \mathrm{E}+11$ & 1572.75 & 1694 & 1335.095 & 26876.38 & 21556.92 & $1.02 \mathrm{E}+09$ \\
\hline Sum Sq. Dev. & $7.38 \mathrm{E}+22$ & 994.1836 & 11965.47 & 1788.65 & 602277.3 & 459401.9 & $7.99 \mathrm{E}+14$ \\
\hline & & & & & & & \\
\hline Observations & 144 & 144 & 144 & 144 & 144 & 144 & 144 \\
\hline
\end{tabular}

\subsection{Toda-Yamamoto (TY) Causality Approach}

The Toda approach operates under the VAR framework which deals with multiple equations. Since more than one variable is used to represent the monetary policy decision for this study, each of them is supposed to have its own equation hence the justification for the VAR techniques. However, after examining the features of the variables which indicated a mixed order of integration, the ordinary VAR technique became inappropriate. To this end, an augmented VAR framework -the TY was employed to investigate the causality relationship between monetary policy and foreign portfolio investment. The TY being a modified version of the Ordinary Granger Causality can overcome the weakness of the ordinary causality by using a modified Wald test for restriction on the parameters of the VAR $(k)$ with $k$ being the lag length of the VAR system. In doing, that the correct order of the system $(k)$ is augmented by the maximum order of integration $\left(d_{\max }\right)$, then the VAR $\left(k+d_{\max }\right)$ is estimated with the coefficients of the last lagged $d_{\max }$ vector being ignored.

\subsection{Model Specification}

An ordinary VAR of order $\mathrm{p}$ can be denoted by:

$$
Y_{t}=\propto_{0}+\propto_{1}+\sum_{i=1}^{P} \beta_{i} Y_{t-1}+\partial w_{t}+\mu_{t}
$$


where $Y_{t}$ is an $(\mathrm{n} \times 1)$ vector of endogenous variables, $\mathrm{t}$ is the linear time trend, $\propto_{0}$ and $\propto_{1}$ are $(\mathrm{n} \times$ 1) vectors, $w_{t}$ is a $(\mathrm{q} \times 1)$ vector of exogenous variables and $\mu_{t}$ is an $(\mathrm{n} \times 1)$ vector of unobserved disturbances. The TY version of VAR $\left(k+d_{\max }\right)$ of order $(\mathrm{p}+\mathrm{d})$ of the model under consideration can be written as:

$$
\begin{gathered}
P F I_{t}=\propto_{0}+\sum_{i=1}^{K} \propto_{1} P F I_{t-1}+\sum_{j=k+1}^{K+d_{\max }} \propto_{2 j} P F I_{t-j}+\ldots \ldots \ldots \ldots \sum_{i=1}^{K} \beta_{1} n_{t-1}+\sum_{j=k+1}^{K+d_{\max }} \beta_{n j} n_{t-j}+ \\
+\mu_{t}
\end{gathered}
$$

$d$ is first-difference operator and the order of $\mathrm{p}$ signifies $\left(k+d_{\max }\right)$.

\subsection{Estimation Process}

The first step in modeling using the TY approach is to ascertain the maximum order of integration $\left(d_{\max }\right)$ of the variables as well as optimal lag length $(k)$ of the VAR system. In establishing the order of integration, an Augmented Dickey-Fuller (ADF) and Phillips-Perron (PP) test were carried out (Table 1). The results revealed that all the series were I (1), except the foreign portfolio investment which was I (0). Since we have a mixed order of integration that does not exceed I (2), it is suitable to employ the TY extended VAR model. After the unit root test, the lag selection test was conducted, and the relevant criteria revealed the optimal lag length of 1,2 , 3 and 7. However only lag 2 passes the stability and LM test. Consequently, lag 2 was chosen as the optimal lag with which the unrestricted VAR was estimated. Following this, the next step is to use the augmented VAR with the maximum order of integration of the variables $\left(d_{\max }\right)$ for estimation.

\subsection{Discussion of Results (Toda-Yamamoto)}

The results of the TY VAR Granger Causality for the equations (appendix 1) showed that the null hypothesis of non-causality from MPR and CRR shocks to FPI was not rejected. This implies that the chosen tools of monetary policy decisions i.e MPR and CCR do not influence foreign portfolio investment. This invalidates the conviction of the CBN presented in the introductory part of this paper. The monetary authority maintained the MPR at 14 percent for long on the ground that reduction in it could result in capital reversal. However, a bidirectional causality was found from treasury bill to foreign portfolio investment and a unidirectional relationship from monetary policy rate and exchange rate shock to treasury bill rate. This finding suggests that since the MPR and exchange rate Granger causes the TB and the TB granger cause the portfolio investment, then monetary policy decision could be said not to influence the decision of foreign portfolio investors directly. In summary, the finding showed that portfolio investment in Nigeria response to treasury bill rate and monetary policy affect the foreign portfolio investment indirectly. This is because the MPR exerted significant influence on the treasury bill rate. Therefore, the TB rate has direct consequences on the performance of the foreign portfolio investment while MPR is just a signaling instrument.

\subsection{Impulse Response Function (IRF)}

The efficacy of the TY Granger causality is limited to in-sample scope. To circumvent this, a generalized IRF and forecast error variance decomposition analysis was employed to argument the TY analysis. The Generalised Impulse response function (GIRF) which is indifferent to ordering trace the effects of any shock characterized by the error term of the equation in question on the future values of the dependent variable in that equation. From the results presented in Figure 4, the GIRF revealed a positive association between MPR and FPI given the impulse of MPR, TBR and the exchange rate on the portfolio investment. Further analysis indicated that innovations from MPR do not affect the outcome of investor's decision contemporaneously from the first month up till the $6^{\text {th }}$ and half month. From the seventh month, the increase in MPR resulted in an increase in portfolio investment by marginal 0.02 percent on average throughout the forecast horizon. This finding is consistent with the TY causality result.

On the other hand, the treasury bill rate impulse affected the foreign portfolio contemporaneously and had an average impact of 0.3 percent on portfolio investment throughout the forecast horizon. Exchange rate depreciation also reacted similarly to the TB rate as foreign portfolio investment responded to its shock in the 
first month contemporaneously up till the second and a half month before it turned negative. However, the cash reserve ratio shock did not affect foreign portfolio investment up to the fourth month. It, however, later, assumed a marginal negative response but return to equilibrium in the tenth month.

In summary, the results suggested that increase in the MPR does not attract foreign portfolio investment to Nigeria in the short-term, and even after the sixth month, the attraction was too infinitesimal for the monetary authority to base its decision to maintain a tight monetary policy stance. This implies that foreign portfolio investors are more worried about TB rates and other issues rather than MPR and CCR in taking investment decisions. The conclusion was that monetary policy is just a signalling instrument through the TB and the exchange rate to foreign portfolio investors.

\section{Response to Cholesky One S.D. Innovations $\pm 2 S . E$.}

Response of LOG(TFPI) to LOG(TFPI)

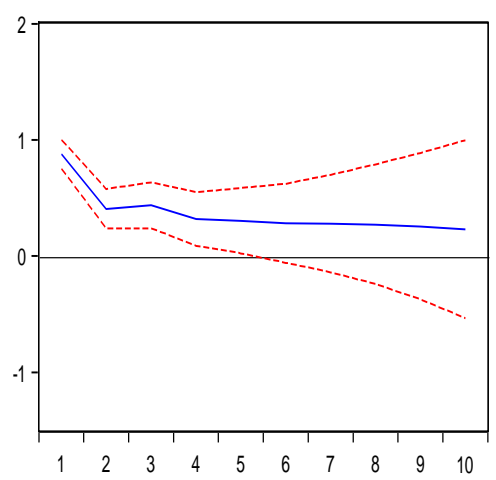

Response of LOG(TFPI) to TB

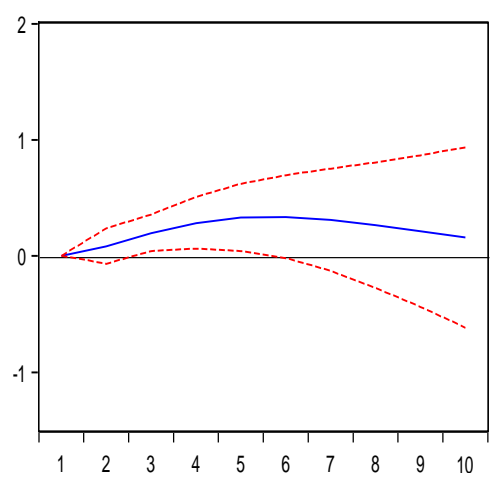

Response of LOG(TFPI) to MPR

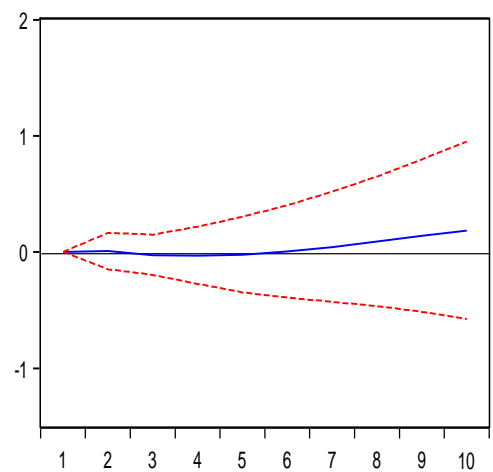

Response of LOG(TFPI) to EIBR

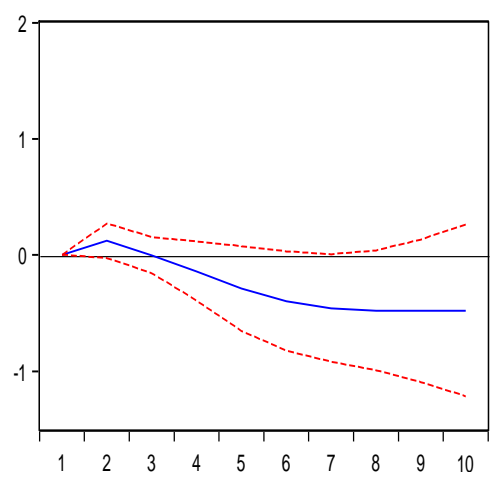

Figure 4. Impulse response graphs
Response of LOG(TFPI) to CCR

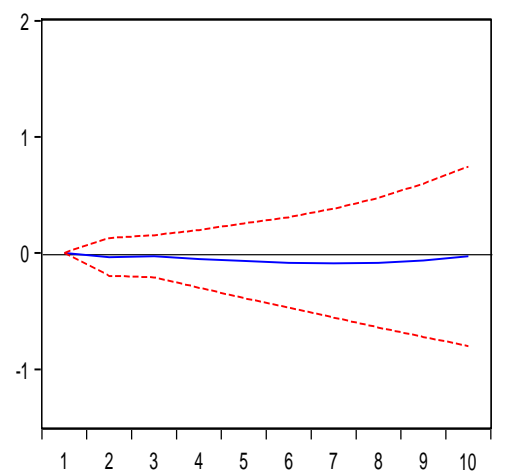

\subsection{Forecast Error Variance Decomposition (FEVD)}

The TY VAR system was estimated to insulate the deviation of each endogenous variable that was due to shocks in each component. The FEVD analysis (appendix 1) indicated that innovations to foreign portfolio investment accounted for 100 percent of the deviation in itself in the first period and settles at 38.8 percent by the end of the tenth month. In the second month, the deviation of foreign portfolio shocks was explained by 0.007 percent variation in MPR, it continued on the average of 0.2 percent throughout the forecast horizon and settled at 1.54 percent by the tenth month. This position validates the finding from the impulse response. Moreover, the cash reserve ratio exhibited a similar impact with the MPR as it explained the variation in foreign portfolio investment with about 0.9 percent on average, up to the tenth month. The treasury bill rate explained the variation in foreign portfolio investment with about 14 percent on average, also consistent with the findings from the TY and GIRF. The exchange rate effect also exerted significant influence from the second month at about 1.5 percent and jumped sharply afterward to 27 percent by the tenth month. This is also consistent with a priori expectation because depreciation in exchange is expected to attract more foreign investment. 


\section{Policy Inference}

The findings showed that monetary policy is just a signalling instrument for portfolio investors in Nigeria because it does not affect portfolio investment directly. This development might imply that other factors besides interest could have influenced investors' decision. The finding also showed that the treasury bill rate is the key interest rate that determines the behaviour of foreign portfolio investors in Nigeria. However, the behaviour of the TB rate itself is explained by the monetary policy rate and the exchange rate. The indirect, as well as the marginal response of monetary policy on portfolio investment, may suggest that monetary policy could still be effective if the CBN decides to lose policy stance without losing significant capital flight. The study also showed that the CBN could depreciate its currency if it desires to attract portfolio inflows.

\section{Conclusion}

The study examines the response of foreign portfolio investment to monetary policy decision in Nigeria from January 2007 to December 2018. The paper used the Toda-Yamamoto augmented VAR model, which can be used irrespective of the order of integration and existence of cointegration. The study found no causality running from MPR and CRR innovations to foreign portfolio investment. However, a bidirectional causality was found between the treasury bill rate and the foreign portfolio investment. Also, a unidirectional causality was found running from MPR and exchange to treasury bill rate.

The article also traced the generalized impulse response paths of foreign portfolio investment to monetary policy innovations. The results showed that changes in monetary policy stance could only impact the behavior of foreign portfolio investment with 6 months lag and with marginal impact. These results may suggest that monetary policy could still be effective if the CBN decides to lose policy stance without losing significant capital flight. The conclusion from the results was that monetary policy is just a signaling instrument for portfolio investors in Nigeria as it affected portfolio investment through its impact on the treasury bill rate. The marginal response from portfolio investment due to changes in policy rate may imply that monetary policy rate changes on its own may not be what investors are concern about, rather the expectation of the rates future path.

\section{References}

Ammera, J., Claessensb, S., Tabovaa, A., \& Wroblewskia, C. (2018). Home Country Interest Rates and International Investment in U.S. Bond. U.S. Fed: International Finance Discussion Papers.

Asal, M. (2011). The Impact of the Euro on Sectoral Equity Returns and Portfolio Risk. International Advances in Economic Research, 17(2), 119-133. https://doi.org/10.1007/s11294-011-9292-5

Ayodele, A. E., Afolabi, B., \& Olaoye, A. C. (2017). Impact of Interest Rate on Portfolio Management in Nigeria. Asian Journal of Economics, Business, and Accounting, 1-10. https://doi.org/10.9734/AJEBA/2017/32882

Bilal, C., Akanimo, U., \& Ademola Y. (2019). The Effects of an Unchanged Monetary Policy Rate in Nigeria's Economic Growth. Nile Journal of Business and Economics. NileJBE, 11, 59-68.

Carvalho, D., \& Fidora, M. (2015). Capital inflows and euro area Long Term Interest Rates. European Central Bank Working Paper Series. https://doi.org/10.1016/j.jimonfin.2015.02.021

Conover, C. M., Jensen, G. R., Johnson, R. R., \& Mercer, J. M. (2005). Is Fed Policy Still Relevant for Investors? Financial Analysts Journal, 70-79. https://doi.org/10.2469/faj.v61.n1.2685

Don, H. K., \& Jonathan, H. W. (2005). An Arbitrage-Free Three-Factor Term Structure Model and the Recent Behavior of Long-Term Yields and Distant-Horizon Forward Rates. Finance and Economics Discussion Series Divisions of Research \& Statistics and Monetary Affairs Federal Reserve Board, Washington, D.C. https://doi.org/10.17016/FEDS.2005.33

Fanelli, S. (2017). Monetary Policy, Capital Controls and International Portfolios. MIT Job Market Paper.

Flageollet, A., \& Bahaji, H. (2016). Monetary Policy and Risk-Based Asset Allocation. Open Economies Review, 27(5), 851-870. https://doi.org/10.1007/s11079-016-9404-1

Fratzscher, M., Saborowski, C., \& Straub, R. (2009). Monetary Policy Shocks and Portfolio Choice. European Central Bank Working Paper Series. https://doi.org/10.24149/gwp25

Golit, P. D., Adamu, Y., \& Belonwu, M. C. (2018). Interest Rates and Investment in Nigeria: Is the Monetary Policy Rate a Signaling Instrument for Portfolio Investors? Economic and Financial Review, 56(4).

Robin, K. (2018). Fed policy expectations and portfolio flows to emerging markets. Journal of International Financial Markets, Institutions \& Money, 55(2018), 170-194. https://doi.org/10.1016/j.intfin.2018.03.003 
Siddiqui, H. A., \& Aumeboonsuke, V. (2014). Role of Interest in Attracting FDI: Study on Asian 5 Economy. International Journal of Technical Research and Applications, 59-70.

Suyuan, L., \& Khurshid, A. (2015). The Effect of Interest Rate on Investment: Empirical Evidence of Jiangsu Province, China: Journal of International Studies, 8(1), 81-90. Database: EconLit with Full Text. https://doi.org/10.14254/2071-8330.2015/8-1/7

Toda, H. Y., \& Yamamoto, T. (1995). Statistical inference in Vector Autoregressions with possibly integrated processes. Journal of Econometrics, 66, 225-250. https://doi.org/10.1016/0304-4076(94)01616-8

Vayanos, D., \& Vila, J. L. (2005). A preferred-habitat model of the term structure of interest rates. National Bureau of Economic Research, Inc NBER Working Papers 15487.

Vinayagathasan, T. (2013). Monetary Policy and Real Economy: A Structural VAR Approach for Sri Lanka. National Graduate Institute for Policy Studies 7-22-1 Roppongi, Minato-ku, Tokyo, Japan 106-8677.

Waqasa, Y., Hashmia, S. H., \& Nazirb, M. I. (2015). Macroeconomic factors and foreign portfolio investment volatility: A Case of South East Asian Countries. Future Business Journal, 65-74. https://doi.org/10.1016/j.fbj.2015.11.002

\section{Appendix}

Unit root test results

\begin{tabular}{|c|c|c|c|c|c|c|c|c|c|c|}
\hline 1 & \multicolumn{5}{|c|}{ Augmented Dickey-Fuller (ADF) } & \multicolumn{5}{|c|}{ Philip Perron (PP) } \\
\hline & $\begin{array}{l}\text { Level } \\
\text { T-Statisti } \\
\text { cs }\end{array}$ & Prob. & $\begin{array}{l}1^{\text {st }} \text { Diff } \\
\text { T-Statisti } \\
\text { cs }\end{array}$ & Prob. & $\begin{array}{l}\text { Order of } \\
\text { Integratio } \\
\text { n }\end{array}$ & $\begin{array}{l}\text { Level } \\
\text { T-Statisti } \\
\text { cs }\end{array}$ & Prob. & $\begin{array}{l}1^{\text {st }} \text { Diff } \\
\text { T-Statisti } \\
\text { cs }\end{array}$ & Prob. & $\begin{array}{l}\text { Order of } \\
\text { Integratio } \\
\text { n }\end{array}$ \\
\hline TFI & -1.916756 & $\begin{array}{l}0.640 \\
6\end{array}$ & -17.49308 & $\begin{array}{l}0.000 \\
0\end{array}$ & I (1) & -3.88321 & $\begin{array}{l}0.015 \\
2\end{array}$ & -19.5849 & $\begin{array}{l}0.000 \\
0\end{array}$ & $\mathrm{I}(0)$ \\
\hline MPR & -0.792428 & $\begin{array}{l}0.817 \\
9 \\
\end{array}$ & -11.38135 & $\begin{array}{l}0.000 \\
0 \\
\end{array}$ & I (1) & -1.00394 & $\begin{array}{l}0.751 \\
0 \\
\end{array}$ & -11.4634 & $\begin{array}{l}0.000 \\
0 \\
\end{array}$ & $\mathrm{I}(1)$ \\
\hline CRR & -2.385143 & $\begin{array}{l}0.385 \\
7\end{array}$ & -11.91402 & $\begin{array}{l}0.000 \\
0\end{array}$ & I (1) & -2.36504 & $\begin{array}{l}0.396 \\
2\end{array}$ & -12.0725 & $\begin{array}{l}0.000 \\
0\end{array}$ & $\mathrm{I}(1)$ \\
\hline TBR & -2.339025 & $\begin{array}{l}0.161 \\
3\end{array}$ & -8.875401 & $\begin{array}{l}0.000 \\
0\end{array}$ & I (1) & -2.15474 & $\begin{array}{l}0.223 \\
9\end{array}$ & -8.87540 & $\begin{array}{l}0.000 \\
0\end{array}$ & $\mathrm{I}(1)$ \\
\hline EIBR & -1.877476 & $\begin{array}{l}0.660 \\
9\end{array}$ & -8.021923 & $\begin{array}{l}0.000 \\
0\end{array}$ & I (1) & -1.86435 & $\begin{array}{l}0.667 \\
7\end{array}$ & -6.73394 & $\begin{array}{l}0.000 \\
0\end{array}$ & $\mathrm{I}(1)$ \\
\hline HCPI & 0.298298 & $\begin{array}{l}0.998 \\
5 \\
\end{array}$ & -5.220564 & $\begin{array}{l}0.000 \\
2\end{array}$ & I (1) & 1.007608 & $\begin{array}{l}0.999 \\
9\end{array}$ & -7.43174 & $\begin{array}{l}0.000 \\
0\end{array}$ & $\mathrm{I}(1)$ \\
\hline & & & & & & & & & & \\
\hline
\end{tabular}

TY VAR Granger

\begin{tabular}{|c|c|c|c|c|c|c|c|c|c|c|}
\hline $\begin{array}{l}\text { RES } \\
\text { V }\end{array}$ & -0.976920 & $\begin{array}{l}0.943 \\
0\end{array}$ & -8.367101 & $\begin{array}{l}0.000 \\
0\end{array}$ & I (1) & -0.81389 & $\begin{array}{l}0.961 \\
2\end{array}$ & -8.38227 & $\begin{array}{l}0.000 \\
0\end{array}$ & $\mathrm{I}(1)$ \\
\hline
\end{tabular}

Notes: ADF 1 and PP 1 represent= Unit root tests with constant, while ADF 2 and PP $2=$ Unit root tests with constant and trend. *,** and *** indicate statistical significance at the $1 \%, 5 \%$ and $10 \%$ level respectively. With constant and trend: McKinnon (1991) critical values are $-4.0496(1 \%),-3.4540(5 \%)$ and $-3.1527(10 \%)$.

VAR Granger Causality/Block Exogeneity Wald Tests

Date: 05/20/19 Time: $14: 23$

Sample: 2007M01 2018M12

Included observations: 140

Dependent variable: LOG(TFPI)

\begin{tabular}{llll} 
Excluded & Chi-sq & df & Prob. \\
\hline \hline & & & \\
MPR & 2.764825 & 3 & 0.4293 \\
CCR & 0.157327 & 3 & 0.9842 \\
TB & 9.115630 & 3 & 0.0278
\end{tabular}




$\begin{array}{llll}\text { EIBR } & 2.656060 & 3 & 0.4477 \\ \text { LOG(HCPI) } & 0.509652 & 3 & 0.9168 \\ \text { LOG(RESV) } & 2.156442 & 3 & 0.5406\end{array}$

\begin{tabular}{llrr}
\hline All & 18.48679 & 18 & 0.4240
\end{tabular}

Dependent variable: MPR

\begin{tabular}{llll}
\hline \hline & Chi-sq & & \\
Excluded & & df & Prob. \\
\hline \hline & & & 0.0334 \\
LOG(TFPI) & 8.707576 & 3 & 0.5743 \\
CCR & 1.991039 & 3 & 0.6749 \\
TB & 1.531997 & 3 & 0.1965 \\
EIBR & 4.683955 & 3 & 0.7515 \\
LOG(HCPI) & 1.206178 & 3 & 0.8122 \\
LOG(RESV) & 0.954786 & & \\
& & & \\
\hline \hline & & 18 & 0.2014 \\
All & 22.72379 & & \\
\hline \hline
\end{tabular}

Dependent variable: $\mathrm{CCR}$

\begin{tabular}{llll}
\hline \hline Excluded & Chi-sq & df & Prob. \\
\hline \hline & & & \\
LOG(TFPI) & 1.318029 & 3 & 0.7249 \\
MPR & 0.919252 & 3 & 0.8208 \\
TB & 1.952945 & 3 & 0.5822 \\
EIBR & 1.929598 & 3 & 0.5871 \\
LOG(HCPI) & 1.124108 & 3 & 0.7713 \\
LOG(RESV) & 1.319444 & & \\
& & & \\
\hline \hline & 7.597423 & 18 & 0.9840 \\
All & & \\
\hline \hline
\end{tabular}

Dependent variable: TB

\begin{tabular}{llll}
\hline \hline Excluded & Chi-sq & df & Prob. \\
\hline \hline & & & \\
LOG(TFPI) & 8.632788 & 3 & 0.0346 \\
MPR & 8.702935 & 3 & 0.0335 \\
CCR & 1.564709 & 3 & 0.6674 \\
EIBR & 13.22390 & 3 & 0.0042 \\
LOG(HCPI) & 13.00844 & 3 & 0.0046 \\
LOG(RESV) & 5.217135 & & 0.1566 \\
& & & \\
\hline \hline & 37.39703 & 18 & 0.0047 \\
All & & \\
\hline \hline
\end{tabular}


Dependent variable: EIBR

\begin{tabular}{llll}
\hline \hline Excluded & Chi-sq & df & Prob. \\
\hline \hline & & & \\
LOG(TFPI) & 2.256460 & 3 & 0.5209 \\
MPR & 4.261543 & 3 & 0.2346 \\
CCR & 0.096668 & 3 & 0.9922 \\
TB & 2.416474 & 3 & 0.4906 \\
LOG(HCPI) & 0.491079 & 3 & 0.9208 \\
LOG(RESV) & 1.566856 & 3 & 0.6669 \\
& & & \\
\hline \hline & 15.55987 & 18 & 0.6232 \\
All & & \\
\hline \hline
\end{tabular}

Dependent variable: LOG(HCPI)

\begin{tabular}{llll}
\hline \hline Excluded & Chi-sq & df & Prob. \\
\hline \hline & & & \\
LOG(TFPI) & 1.284780 & 3 & 0.7328 \\
MPR & 3.557790 & 3 & 0.3133 \\
CCR & 0.523925 & 3 & 0.9136 \\
TB & 5.625113 & 3 & 0.1313 \\
EIBR & 5.211872 & 3 & 0.5124 \\
LOG(RESV) & 2.300578 & 3 & \\
& & & 0.6348 \\
\hline \hline
\end{tabular}

Dependent variable: LOG(RESV)

\begin{tabular}{llll}
\hline \hline Excluded & Chi-sq & df & Prob. \\
\hline \hline & & & \\
LOG(TFPI) & 2.119102 & 3 & 0.5481 \\
MPR & 7.164679 & 3 & 0.0668 \\
CCR & 3.968134 & 3 & 0.2649 \\
TB & 7.743532 & 3 & 0.0516 \\
EIBR & 15.40474 & 3 & 0.0015 \\
LOG(HCPI) & 1.913364 & 3 & \\
& & & 0.0252 \\
\hline \hline
\end{tabular}


IMPULSE

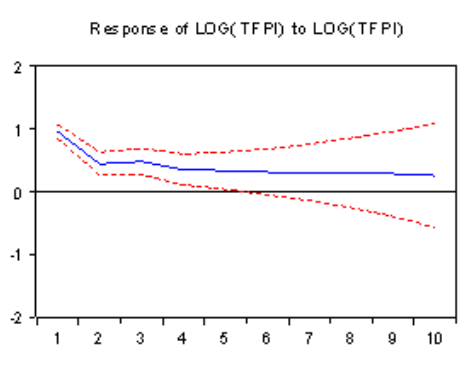

Resporse of LOG(TFPI) to TB

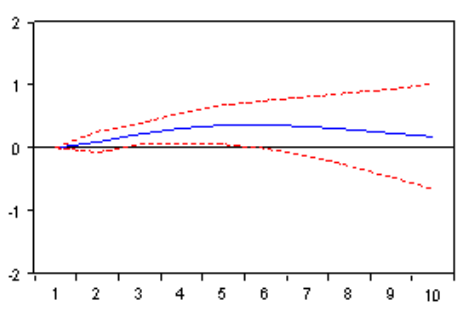

Response of LOG(TFPI) to LOG(RESW

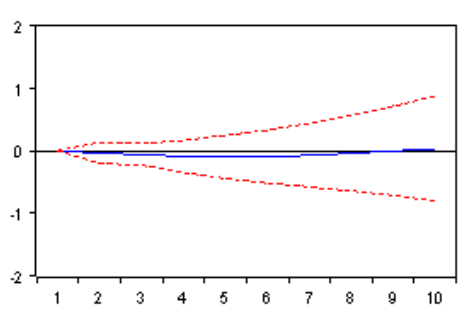

RESPOSE

Response to Cholesky One S.D. Innow ations \pm 2 S.E.

Res porse of $L O G(T F P D)$ to MPR

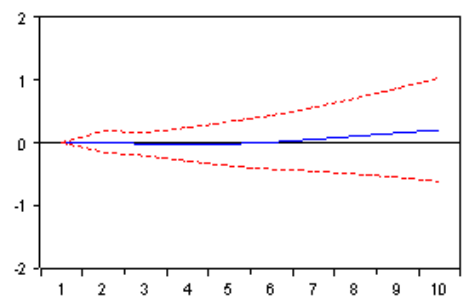

Response of LOG(TFPI) to ElBR

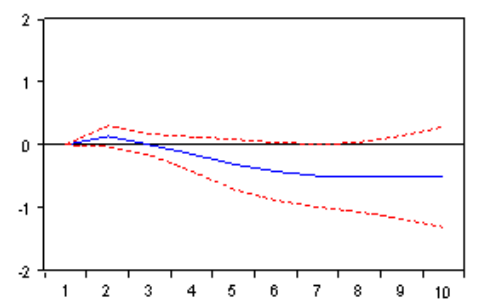

FUNCTION

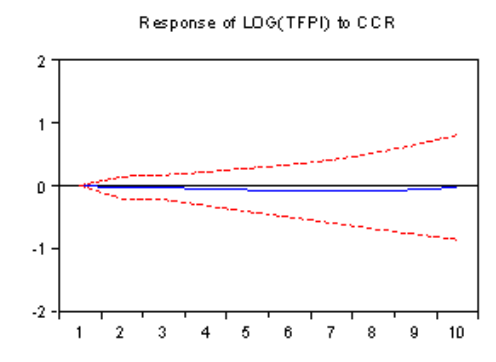

Resporse of LOG(TFPI) to LOG(HCPI)

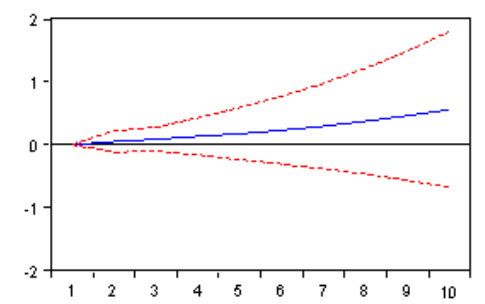

Forecast error variance decomposition

\begin{tabular}{|c|c|c|c|c|c|c|c|c|}
\hline Period & S.E. & LOG(TFPI) & MPR & CCR & TB & EIBR & LOG(HCPI) & LOG(RESV) \\
\hline \multirow[t]{2}{*}{1} & \multirow[t]{2}{*}{0.953527} & 100.0000 & 0.000000 & 0.000000 & 0.000000 & 0.000000 & 0.000000 & 0.000000 \\
\hline & & $(0.00000)$ & $(0.00000)$ & $(0.00000)$ & $(0.00000)$ & $(0.00000)$ & $(0.00000)$ & $(0.00000)$ \\
\hline \multirow[t]{2}{*}{2} & \multirow[t]{2}{*}{1.065312} & 97.23119 & 0.006709 & 0.134216 & 0.726946 & 1.553901 & 0.198766 & 0.148275 \\
\hline & & (2.93709) & $(0.88236)$ & $(0.91396)$ & (1.91758) & $(1.75747)$ & (1.02328) & $(0.96479)$ \\
\hline \multirow[t]{2}{*}{3} & \multirow[t]{2}{*}{1.191117} & 93.61624 & 0.059035 & 0.175934 & 3.824886 & 1.243068 & 0.693232 & 0.387602 \\
\hline & & $(3.66941)$ & (1.12615) & $(1.27248)$ & (2.99552) & $(1.48443)$ & (1.64344) & $(1.25166)$ \\
\hline \multirow[t]{2}{*}{4} & \multirow[t]{2}{*}{1.298516} & 85.85293 & 0.110054 & 0.340215 & 8.869364 & 2.411125 & 1.598192 & 0.818115 \\
\hline & & (6.52010) & (1.98099) & $(2.40240)$ & (5.07012) & (3.18917) & (3.64134) & $(2.28200)$ \\
\hline \multirow[t]{2}{*}{5} & \multirow{2}{*}{1.439296} & 75.13793 & 0.121882 & 0.537700 & 13.49354 & 6.762433 & 2.779989 & 1.166522 \\
\hline & & (9.73480) & $(3.03665)$ & (3.31757) & (7.03105) & $(7.16663)$ & $(6.25234)$ & (3.49694) \\
\hline \multirow[t]{2}{*}{6} & \multirow{2}{*}{1.598610} & 64.59025 & 0.099467 & 0.755213 & 16.18992 & 12.75415 & 4.309598 & 1.301404 \\
\hline & & (11.4100) & $(4.13449)$ & $(4.08848)$ & $(8.36420)$ & $(10.4078)$ & $(8.86312)$ & $(4.80435)$ \\
\hline \multirow[t]{2}{*}{7} & \multirow[t]{2}{*}{1.764538} & 55.98576 & 0.154940 & 0.921651 & 16.95206 & 18.41768 & 6.329967 & 1.237948 \\
\hline & & (12.0337) & $(5.35065)$ & $(4.71472)$ & $(8.94227)$ & $(12.1168)$ & (11.2744) & $(6.18465)$ \\
\hline \multirow[t]{2}{*}{8} & \multirow[t]{2}{*}{1.927137} & 49.27516 & 0.396712 & 0.995854 & 16.45304 & 22.74613 & 9.051754 & 1.081354 \\
\hline & & (12.3873) & $(6.68874)$ & $(5.42243)$ & (8.90689) & $(12.7940)$ & (13.3261) & $(7.47329)$ \\
\hline \multirow[t]{2}{*}{9} & \multirow[t]{2}{*}{2.087763} & 43.76399 & 0.868746 & 0.958857 & 15.24397 & 25.63646 & 12.60625 & 0.921730 \\
\hline & & $(12.7592)$ & $(7.99830)$ & $(6.22449)$ & $(8.49617)$ & $(13.0607)$ & $(14.9745)$ & $(8.46991)$ \\
\hline \multirow[t]{2}{*}{10} & \multirow[t]{2}{*}{2.253533} & 38.80839 & 1.545732 & 0.842083 & 13.67160 & 27.33511 & 16.98844 & 0.808640 \\
\hline & & (13.0704) & $(9.11776)$ & $(7.06880)$ & $(8.00485)$ & $(13.1480)$ & $(16.3402)$ & $(9.16736)$ \\
\hline
\end{tabular}




\section{Stability test result}

Roots of Characteristic Polynomial

Endogenous variables: LOG(TFPI) MPR CCR TB EIBR LOG(HCPI) LOG(RESV)

Exogenous variables: $\mathrm{C}$

Lag specification: 12

Date: 05/20/19 Time: 15:32

\begin{tabular}{ll}
\hline \hline Root & Modulus \\
\hline \hline & \\
$0.998743-0.056042 \mathrm{i}$ & 0.998743 \\
$0.958913-0.960549$ \\
$0.958913+0.056042 \mathrm{i}$ & 0.960549 \\
$0.939429-0.065048 \mathrm{i}$ & 0.941679 \\
$0.939429+0.065048 \mathrm{i}$ & 0.941679 \\
$0.699676-0.163629 \mathrm{i}$ & 0.718555 \\
$0.699676+0.163629 \mathrm{i}$ & 0.718555 \\
0.446150 & 0.446150 \\
-0.303316 & 0.303316 \\
$0.234731-0.111889 \mathrm{i}$ & 0.260034 \\
$0.234731+0.111889 \mathrm{i}$ & 0.260034 \\
0.237899 & 0.237899 \\
-0.024234 & 0.024234 \\
0.020658 & 0.020658 \\
\hline \hline
\end{tabular}

No root lies outside the unit circle.

VAR satisfies the stability condition.

VAR Residual Serial Correlation LM Tests

Null Hypothesis: no serial correlation at lag order $\mathrm{h}$

Date: 05/20/19 Time: 15:33

Sample: 2007M01 2018M12

Included observations: 142

\begin{tabular}{lll}
\hline \hline & & \\
Lags & LM-Stat & Prob \\
& & \\
\hline \hline & & \\
1 & 81.71638 & 0.0023 \\
2 & 60.65377 & 0.1228 \\
3 & 78.62281 & 0.0046 \\
4 & 57.64667 & 0.1859 \\
5 & 47.80528 & 0.5216 \\
6 & 72.60795 & 0.0159 \\
7 & 47.35684 & 0.5399 \\
8 & 50.62787 & 0.4091 \\
9 & 51.00353 & 0.3948 \\
10 & 35.95349 & 0.9175 \\
11 & 39.85535 & 0.8212 \\
12 & 50.59326 & 0.4104 \\
& & \\
\hline \hline
\end{tabular}

Probs from chi-square with $49 \mathrm{df}$.

VAR Lag Order Selection Criteria

Endogenous variables: LOG(TFPI) MPR CCR TB EIBR LOG(HCPI) LOG(RESV)

Exogenous variables: $\mathrm{C}$

Date: 05/20/19 Time: 15:34

Sample: 2007M01 2018M12

Included observations: 134

\begin{tabular}{lllllll}
\hline \hline Lag & LogL & LR & FPE & AIC & SC & HQ
\end{tabular}




\begin{tabular}{|c|c|c|c|c|c|c|}
\hline 0 & -1702.371 & NA & 283.6849 & 25.51300 & 25.66438 & 25.57452 \\
\hline 1 & -318.2068 & 2603.055 & $6.29 \mathrm{e}-07$ & 5.585176 & $6.796214^{*}$ & $6.077303 *$ \\
\hline 2 & -268.5153 & 88.25807 & $6.26 \mathrm{e}-07$ & $5.574855^{*}$ & 7.845550 & 6.497592 \\
\hline 3 & -215.2658 & 89.01398 & $5.96 \mathrm{e}-07^{*}$ & 5.511431 & 8.841784 & 6.864779 \\
\hline 4 & -167.6276 & 74.65692 & $6.26 \mathrm{e}-07$ & 5.531756 & 9.921767 & 7.315714 \\
\hline 5 & -120.4100 & 69.06454 & $6.73 e-07$ & 5.558359 & 11.00803 & 7.772928 \\
\hline 6 & -91.53333 & 39.22059 & $9.74 \mathrm{e}-07$ & 5.858706 & 12.36803 & 8.503887 \\
\hline 7 & -18.62919 & $91.40220 *$ & $7.54 \mathrm{e}-07$ & 5.501928 & 13.07091 & 8.577719 \\
\hline 8 & 22.44516 & 47.20485 & $9.75 \mathrm{e}-07$ & 5.620222 & 14.24886 & 9.126623 \\
\hline 9 & 85.52459 & 65.90388 & $9.53 e-07$ & 5.410081 & 15.09838 & 9.347093 \\
\hline 10 & 138.2029 & 49.53333 & $1.16 \mathrm{e}-06$ & $5.355181^{*}$ & 16.10314 & 9.722804 \\
\hline
\end{tabular}

* indicates lag order selected by the criterion

LR: sequential modified LR test statistic (each test at 5\% level)

FPE: Final prediction error

AIC: Akaike information criterion

SC: Schwarz information criterion

HQ: Hannan-Quinn information citerions

\section{Copyrights}

Copyright for this article is retained by the author(s), with first publication rights granted to the journal.

This is an open-access article distributed under the terms and conditions of the Creative Commons Attribution license (http://creativecommons.org/licenses/by/4.0/). 